\section{Antioxidants in flour of the oilseed crop Camelina sativa (L.) Crantz}

\author{
Roberto Russo, Remo Reggiani \\ Istituto di Biologia e Biotecnologia \\ Agraria, CNR, Milano, Italy
}

\begin{abstract}
Forty-seven accessions of Camelina sativa (L.) Crants (41 spring and 6 winter forms) were analyzed for antioxidant activity, total phenolic content (TPC), flavonoids and proanthocyanidins. The antioxidant activity (AA\%) was high in camelina accessions and with a significant variability among accessions and between spring and winter forms. The highest antioxidant activities have been observed in some spring accessions (CAM35, CAM173 and CAM268). TPC was high in camelina and significantly different among accessions. Antioxidant activity resulted highly correlated with TPC, while no correlation was observed with flavonoid and proanthocyanidin contents. Significant variability was observed among accessions but not between groups (winter and spring) for flavonoid and proanthocyanidin contents. These two classes of compounds showed a significant inverse correlation between them suggesting that their synthesis is in competition. The camelina cake can enrich the animal diet of antioxidant compounds (phenolics) and some spring accessions are more promising for future breeding programs.
\end{abstract}

\section{Introduction}

Camelina sativa (L.) Crantz also known as false flax, is an annual oilseed crop with both autumn and spring biotypes and belongs to the brassica family. The interest for this plant has grown recently because it is a low-input crop. In fact, it can grow well on marginal lands (semiarid, low fertile or saline soils). Camelina sativa is tolerant to cold and drought and it does not require much chemistry (fertilizers, herbicides and pesticides). ${ }^{1}$ Its oil is highly unsaturated $(>90 \%)$ with a profile rich in $\alpha$-linolenic $\mathrm{acid}^{2}$ which make it suitable for non-feed (jetfuel) or feed applications. ${ }^{3}$

Meal resulting from oil extraction has a remarkable potential economic value as an ingredient for animal nutrition. ${ }^{4,5}$ Camelina flour contains $290-370 \mathrm{mg} \mathrm{g}^{-1}$ of crude pro- tein with a favorable amino acid composition. ${ }^{5}$ The use of camelina meal for animal feed is limited by the presence of glucosinolates. Usage limit is $10 \%$ in USA and $12 \%$ in Canada. ${ }^{6,7}$ In the EU, the use has been legalized by Directive 2008/76/EC. ${ }^{8}$ The glucosinolates allowed in EU was set at 1.5 mmol kg-1 of feed for monogastric animals. However, there is a great variability in glucosinolate content between camelina accessions and some accessions have more favorable glucosinolate contents. ${ }^{9}$

Camelina flour also brings a considerable amount of antioxidant compounds to diets. ${ }^{10,11}$ In general, the oil extraction process leads to an increase in antioxidant activity and compounds related to this activity (phenolics, flavonoids and tannins). ${ }^{3}$ In the present study, the variability inside a collection of 47 camelina accessions (41 spring and 6 winter biotypes) for antioxidant activity, phenolics, flavonoids and proanthocyanidins (tannins) was assessed in order to identify useful accessions for breeding programs aimed at camelina flour enriched in antioxidants.

\section{Materials and Methods}

\section{Reagents and plant materials}

DPPH, Folin-Ciocalteu, caffeic acid, catechin, $\mathrm{Na}_{2} \mathrm{CO}_{3}, \mathrm{NaNO}_{2}$ and $\mathrm{AlCl}_{3}$ were purchased from Sigma-Aldrich (Milan, Italy). All organic solvents were analytical grade. Seeds of all the accesses of Camelina sativa L. were kindly provided by IPK genebank (Germany) with the exception of the PI650142, PI650146 and PI650168 accessions provided by USDA (USA), KARTNER, MORGENSONNE and ST. PERNITZEN accessions provided by Arche Noah genebank (Austria) and accession CAMELIA gifted by Panghea Natural and Chemical Innovation (Milan, Italy). For the origin of these accessions see Russo and Reggiani. ${ }^{9}$ Only six accessions were winter forms (CAM37, CAM76, CAM132, PI650168, WILEDO, ZARJA SOCIALISMA) and therefore were exposed to low temperatures for a short time after germination. All varieties were reproduced in pots with commercial soil. After harvesting, the camelina seeds were ground in mortar and the fat extracted with hexane (defatted flour).

\section{Antioxidant activity assay}

Samples were prepared by extracting camelina flour with ethanol using a ratio of 1:10 (w/v). Antioxidant activity was determined as DPPH radical scavenging activity according to methodology described by
Correspondence: Remo Reggiani, Istituto di Biologia e Biotecnologia Agraria, CNR, via Corti 12, 20133 Milano, Italy.

Tel.: +39.02.23699416 - Fax: +39.02.23699411.

E-mail: reggiani@ibba.cnr.it

Key words: Antioxidant activity; Camelina sativa $\mathrm{L}$. Crantz; flavonoids; phenolics; proanthocyanidins.

Contributions: the authors contributed equally.

Conflict of interests: the authors declare no potential conflict of interests.

Funding: this work has been supported by Fondazione Cariplo, grant no. 2015-0408.

Received for publication: 27 February 2018. Accepted for publication: 9 May 2018.

This work is licensed under a Creative Commons Attribution-NonCommercial 4.0 International License (CC BY-NC 4.0).

(C) Copyright R. Russo and R. Reggiani, 2018 Licensee PAGEPress srl, Italy International Journal of Plant Biology 2018; 9:7659 doi:10.4081/pb.20187.7659

Brand-Williams et al. ${ }^{12}$ The reaction mixture included $50 \mu \mathrm{L}$ of alcoholic extract or trolox $(2-50 \mathrm{nmol}), 300 \mu \mathrm{L}$ of ethanol and $30 \mu \mathrm{L}$ of $0.5 \mathrm{mM}$ DPPH in ethanol. In the control, $50 \mu \mathrm{L}$ of ethanol replaced the extract. In the blank, ethanol replaced the DPPH. When DPPH reacts with antioxidant compounds can donate hydrogen and in its reduced form change color. After $100 \mathrm{~min}$ of reaction, the samples were transferred to 96-well transparent plates and the $517 \mathrm{~nm}$ absorbance read through the Infinite M200 PRO microplate reader (Tecan Italia Srl, Cernusco sul Naviglio, Italy).

The antioxidant activity was expressed both as trolox equivalent antioxidant capacity (TEAC) and as scavenging activity percentage (AA\%) according to this formula $\mathrm{AA} \%=100-\left[\left(\mathrm{Abs}_{\text {sample }}-\mathrm{Abs}_{\text {blank }}\right) \times 100 /\right.$ $\left.\mathrm{Abs}_{\text {control }}\right],{ }^{13}$ where $\mathrm{Abs}_{\text {sample }}, \mathrm{ABS}_{\text {blank }}$ and $\mathrm{Abs}_{\text {control }}$ are absorbances of sample, blank and control.

\section{Total phenolics, flavonoids and proanthocyanidins analyses}

The total phenolic content (TPC) was determined according to the FolinCiocalteu method. ${ }^{14}$ Phenols were extracted from defatted flours with $80 \%$ ethanol at $70^{\circ} \mathrm{C}$. The reaction mixture was composed by $100 \mu \mathrm{l}$ of alcoholic extract or caffeic acid standard (50-400 $\mu \mathrm{g})$ and $500 \mu \mathrm{L}$ of FolinCiocalteu reagent (diluted 2 -fold with distilled water). The samples were allowed to 
stand at room temperature for $5 \mathrm{~min}$ and then $400 \mu \mathrm{L}$ of $60 \mathrm{~g} \mathrm{~L}^{-1}$ of $\mathrm{Na}_{2} \mathrm{CO}_{3}$ solution were added. The test tubes were mixed and heated at $45^{\circ} \mathrm{C}$ for $15 \mathrm{~min}$. The samples were allowed to rest for $30 \mathrm{~min}$ at room temperature in the dark and then the absorbance was measured at $765 \mathrm{~nm}$. Eighty\% ethanol was used as a blank and the results were expressed as caffeic acid equivalents per $\mathrm{kg}$ of dry weight (mg CAE $\mathrm{g}^{-1}$ DW).

Samples for flavonoid determination were extracted with methanol using a ratio of $1: 10(\mathrm{w} / \mathrm{v})$. To $100 \mu \mathrm{L}$ of alcoholic extract were added $400 \mu \mathrm{L}$ of water, $30 \mu \mathrm{L}$ $5 \% \mathrm{NaNO}_{2}$ and mixed. The tubes were allowed to stand for $5 \mathrm{~min}$ before that $30 \mu \mathrm{L}$ of $10 \% \mathrm{AlCl}_{3}$ were added. After $1 \mathrm{~min}$, to each sample were added $200 \mu \mathrm{L} 1 \mathrm{M} \mathrm{NaOH}$ and $240 \mu \mathrm{L}$ of water. The reaction mixture was then centrifuged and allowed to stand for $15 \mathrm{~min}$ in the dark. The samples (300 $\mu \mathrm{L}$ ) were transferred to 96 -well transparent plates and the absorbance read at $510 \mathrm{~nm}$ against a blank (where sample was replaced with methanol). Flavonoid content was calculated from a standard curve of catechin (5-60 $\mu \mathrm{g})$.

Proanthocyanidins (tannins) were extracted from defatted flours with $70 \%$ acetone twice (at 1:10 w/v ratio). The extracts were evaporated to dryness and resuspended in methanol. Proanthocyanidins were assayed by the vanillin method according to Butler et al. ${ }^{15}$ using catechin as standard $(50-200 \mu \mathrm{g})$. The absorbance of the samples and standards was read at $500 \mathrm{~nm}$.

\section{Statistical analysis}

Statistical analysis was carried out using SPSS version 11.5 software. The extraction of each accession was performed in triplicate. For camelina flours, the model included the accession or the group (wintersprings biotypes) as the fixed effect and the sample as a random effect. Means, standard errors and Pearson's correlations were calculated and the mean separations were obtained by Tukey's range test $(\mathrm{P}<0.05)$.

\section{Results and Discussion}

\section{Antioxidant activity}

The antioxidant activity in camelina accessions expressed as TEAC and AA\% is shown in Table 1. The ANOVA showed that the differences in TEAC and AA\% among accessions are significant at 0.01 level. In general, antioxidant activity was extremely high in camelina flour with an AA\% mean value of 92.8 . This datum confirms that
Table 1. Trolox equivalent antioxidant capacity (TEAC) and antioxidant activity percentage (AA\%) in 47 different accessions of Camelina sativa.

\begin{tabular}{|c|c|c|}
\hline Accessions & TEAC $^{\circ}$ & $\mathrm{AA} \%$ \\
\hline BAVARIA & $14.6 \pm 0.12($ cdefg $)$ & $93.9 \pm 0.4$ \\
\hline CALENA & $14.5 \pm 0.01$ (cdefgh) & $93.6 \pm 0.1$ \\
\hline CAM7 & $14.4 \pm 0.17$ (cdefgh) & $93.2 \pm 0.6$ \\
\hline CAM8 & $14.0 \pm 0.08(\mathrm{gh})$ & $91.9 \pm 0.3$ \\
\hline CAM25 & $14.4 \pm 0.09$ (cdefgh) & $93.1 \pm 0.3$ \\
\hline CAM29 & $14.4 \pm 0.14$ (cdefgh) & $93.3 \pm 0.5$ \\
\hline CAM31 & $14.4 \pm 0.17$ (cdefgh) & $93.2 \pm 0.6$ \\
\hline CAM34 & $14.6 \pm 0.04$ (cdefg) & $94.0 \pm 0.1$ \\
\hline CAM35 & $15.6 \pm 0.12(\mathrm{a})$ & $97.2 \pm 0.4$ \\
\hline CAM $37^{*}$ & $12.9 \pm 0.20$ (i) & $88.1 \pm 0.7$ \\
\hline CAM38 & $14.7 \pm 0.06$ (cdefg) & $94.1 \pm 0.2$ \\
\hline CAM39 & $13.8 \pm 0.29(\mathrm{~h})$ & $91.4 \pm 1.0$ \\
\hline CAM58 & $14.4 \pm 0.09$ (cdefgh) & $93.1 \pm 0.3$ \\
\hline CAM76* & $10.9 \pm 0.14(\mathrm{k})$ & $81.1 \pm 0.5$ \\
\hline CAM108 & $14.7 \pm 0.21$ (cdefg) & $94.4 \pm 0.7$ \\
\hline CAM110 & $14.6 \pm 0.05$ (cdefg) & $94.0 \pm 0.2$ \\
\hline CAM111 & $14.9 \pm 0.09$ (bcde) & $94.8 \pm 0.3$ \\
\hline CAM116 & $12.8 \pm 0.08$ (i) & $87.8 \pm 0.3$ \\
\hline CAM123 & $14.6 \pm 0.05$ (cdefg) & $93.9 \pm 0.2$ \\
\hline CAM132* & $15.0 \pm 0.05(\mathrm{abcd})$ & $95.2 \pm 0.2$ \\
\hline CAM136 & $14.6 \pm 0.04$ (cdefg) & $94.0 \pm 0.2$ \\
\hline CAM137 & $14.8 \pm 0.11$ (cdef) & $94.7 \pm 0.3$ \\
\hline CAM170 & $14.7 \pm 0.10$ (cdefg) & $94.1 \pm 0.3$ \\
\hline CAM171 & $14.3 \pm 0.14$ (defgh) & $92.9 \pm 0.5$ \\
\hline CAM173 & $15.6 \pm 0.08$ (a) & $97.2 \pm 0.3$ \\
\hline CAM174 & $14.1 \pm 0.09(\mathrm{fgh})$ & $92.2 \pm 0.3$ \\
\hline CAM175 & $10.7 \pm 0.14(\mathrm{k})$ & $80.1 \pm 0.6$ \\
\hline CAM187 & $13.8 \pm 0.29(\mathrm{~h})$ & $91.4 \pm 1.0$ \\
\hline CAM265 & $14.6 \pm 0.05$ (cdefg) & $94.0 \pm 0.2$ \\
\hline CAM266 & $14.6 \pm 0.04$ (cdefg) & $94.0 \pm 0.1$ \\
\hline CAM268 & $15.6 \pm 0.12(\mathrm{a})$ & $97.2 \pm 0.4$ \\
\hline CAM 269 & $12.9 \pm 0.20$ (i) & $88.1 \pm 0.7$ \\
\hline CAM270 & $14.7 \pm 0.06$ (cdefg) & $94.1 \pm 0.2$ \\
\hline CAMELIA & $15.0 \pm 0.23(\mathrm{abc})$ & $95.4 \pm 0.7$ \\
\hline KARTNER & $14.3 \pm 0.01$ (defgh) & $92.8 \pm 0.1$ \\
\hline LIGENA & $11.9 \pm 0.08(\mathrm{j})$ & $84.6 \pm 0.3$ \\
\hline LINDO & $14.5 \pm 0.03$ (cdefgh) & $93.6 \pm 0.1$ \\
\hline MORGENSONNE & $14.4 \pm 0.10$ (cdefgh) & $93.3 \pm 0.3$ \\
\hline PI650142 & $14.0 \pm 0.03(\mathrm{gh})$ & $92.0 \pm 0.1$ \\
\hline PI650146 & $15.5 \pm 0.20(\mathrm{ab})$ & $96.8 \pm 0.6$ \\
\hline PI650168* & $14.7 \pm 0.21$ (cdefg) & $94.4 \pm 0.7$ \\
\hline SOLEDO & $14.7 \pm 0.09$ (cdefg) & $94.2 \pm 0.3$ \\
\hline ST. PERNITZEN & $14.9 \pm 0.09$ (bcde) & $94.8 \pm 0.3$ \\
\hline UKRAJINSKAJA & $15.1 \pm 0.06(\mathrm{abc})$ & $95.5 \pm 0.2$ \\
\hline WILEDO* & $14.2 \pm 0.15$ (efgh) & $92.7 \pm 0.5$ \\
\hline WROCLAWSKA & $14.6 \pm 0.27$ (cdefg) & $94.0 \pm 0.9$ \\
\hline ZARJA SOCIALISMA* & $14.7 \pm 0.05$ (cdefg) & $94.1 \pm 0.2$ \\
\hline Mean & $14.3 \pm 0.17$ & $92.8 \pm 0.1$ \\
\hline P accession & $58.55^{\S}$ & $63.19^{\S}$ \\
\hline$\underline{\text { Proup }}$ gr $^{\#}$ & $6.07^{\wedge}$ & $6.17^{\wedge}$ \\
\hline
\end{tabular}

*Camelina winter forms; ${ }^{\circ}$ Data are expressed as mmol Trolox $\mathrm{g}^{-1} \mathrm{DW} \pm \mathrm{SEM}$; \#groups are winter and spring biotypes; ${ }^{\S}$ Significant at $\leq 0.01$; $\wedge$ Significant at $\leq 0.05$; the lowercase letters in parentheses within the same row differ significantly by Tukey's range test ( $\mathrm{P} \leq 0.05)$. 
observed by Aziza et al. ${ }^{11}$ In absolute terms, the antioxidant activity is higher than that described by Quezada and Cherian ${ }^{3}$ with

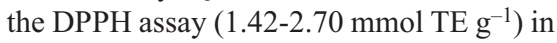
camelina low-high fat meal and lower than that reported by Rahman et al. ${ }^{16}$ for defatted meal. Moreover, The ANOVA showed significant differences at 0.05 level among groups (winter $v s$ spring accessions) and this is due to the fact that the accessions with the highest antioxidant activities are all springs (CAM35, CAM173 and CAM268; letters a by the Tukey's range test).

\section{Phenolic, flavonoid and proantho- cyanidin contents}

The TPC was determined in 47 camelina accessions by the Folin-Ciocalteu method. Table 2 shows that the TPC ranged

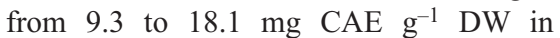
camelina flour with an average of 13.6. These values are in the same range to that reported previously in camelina ${ }^{16}$ and significantly higher than other species rich in phenolics ${ }^{17-19}$ Significant differences at 0.01 level among accessions and groups were evidenced by ANOVA analysis. The highest phenolic contents were observed in CAM266, PI650146 and CAM58 (17.9, 18.1 and $17.5 \mathrm{mg} \mathrm{CAE} \mathrm{g}^{-1} \mathrm{DW}$, respectively).

The ANOVA showed that the differences in flavonoids among accessions are significant at 0.01 level while no differences are present between groups (Table 2). The mean flavonoid content in camelina was $3.60 \mathrm{mg} \mathrm{g}^{-1} \mathrm{DW}$, which is lower than that reported by Aziza et al. and Rahman et al. ${ }^{11,16}$ but higher respect to Salminen et $a l .{ }^{20}$ The accessions BAVARIA, SOLEDO and ZARJA SOCIALISMA were the richest in flavonoids (letters a and b by the Tukey's range test).

Proanthocyanidins (flavan-3-ol based biopolymers) may be anti-nutritional factors when they are concentrated in plant tissues otherwise they may have an antioxidant function due to the presence of numerous phenolic groups. As their content is relatively low in camelina, ${ }^{21,22}$ they can be more important as antioxidants than as antinutritional compounds. Significant differences at 0.01 level among accessions for proanthocyanidins were evidenced by ANOVA analysis but not between groups (Table 2). The mean proanthocyanidins content in camelina was $5.20 \mathrm{mg} \mathrm{g}^{-1} \mathrm{DW}$ but many accessions have contents close to $3.60 \mathrm{mg} \mathrm{g}^{-1} \mathrm{DW}$ as described by Rahman et al. ${ }^{16}$ The accessions CAM58, CAM132, CAM170 and CAM171 showed the highest tannins contents (letters $\mathrm{a}$ and $\mathrm{b}$ by the Tukey's range test).
Table 2. Total phenolic content (TPC), flavonoids and proanthocyanidins in 47 different accessions of Camelina sativa.

\begin{tabular}{|c|c|c|c|}
\hline Accessions & $\mathrm{TPC}^{\circ}$ & Flavonoids ${ }^{\#}$ & Proanthocyanidins \\
\hline BAVARIA & $13.6 \pm 0.02(\mathrm{klm})$ & $4.78 \pm 0.01(\mathrm{a})$ & $3.57 \pm 0.07$ (rs) \\
\hline CALENA & $11.9 \pm 0.04(\mathrm{u})$ & $3.57 \pm 0.02$ (hi) & $3.66 \pm 0.08(\mathrm{r})$ \\
\hline CAM7 & $16.3 \pm 0.04(\mathrm{e})$ & $4.65 \pm 0.03(\mathrm{~b})$ & $5.86 \pm 0.10(\mathrm{efgh})$ \\
\hline CAM8 & $16.3 \pm 0.02(\mathrm{e})$ & $3.89 \pm 0.04$ (f) & $3.78 \pm 0.07$ (qr) \\
\hline CAM25 & $16.1 \pm 0.10(\mathrm{e})$ & $2.95 \pm 0.01(\mathrm{r})$ & $5.70 \pm 0.02$ (hi) \\
\hline CAM29 & $16.0 \pm 0.05$ (ef) & $3.84 \pm 0.02(\mathrm{fg})$ & $4.40 \pm 0.03(0)$ \\
\hline CAM31 & $11.1 \pm 0.09$ (vw) & $3.39 \pm 0.01(\mathrm{kl})$ & $5.87 \pm 0.10(\mathrm{efgh})$ \\
\hline CAM34 & $11.4 \pm 0.07(\mathrm{v})$ & $3.18 \pm 0.02(0)$ & $6.02 \pm 0.06(\mathrm{efg})$ \\
\hline CAM35 & $14.8 \pm 0.06(\mathrm{~g})$ & $4.00 \pm 0.05(\mathrm{e})$ & $6.41 \pm 0.15(\mathrm{c})$ \\
\hline CAM $37^{*}$ & $9.3 \pm 0.06(\mathrm{z})$ & $3.36 \pm 0.01(\mathrm{~lm})$ & $6.41 \pm 0.14(\mathrm{c})$ \\
\hline CAM38 & $15.0 \pm 0.12(\mathrm{~g})$ & $4.51 \pm 0.01(\mathrm{c})$ & $6.08 \pm 0.10(\mathrm{def})$ \\
\hline CAM39 & $12.7 \pm 0.06(\mathrm{~s})$ & $2.92 \pm 0.02(r)$ & $6.01 \pm 0.06(\mathrm{efgh})$ \\
\hline CAM58 & $17.5 \pm 0.06$ (b) & $3.47 \pm 0.02(\mathrm{ijk})$ & $6.98 \pm 0.01$ (b) \\
\hline CAM76* & $13.4 \pm 0.06$ (op) & $3.54 \pm 0.01$ (hi) & $5.83 \pm 0.09(\mathrm{efgh})$ \\
\hline CAM108 & $9.8 \pm 0.07(\mathrm{y})$ & $3.51 \pm 0.01$ (hij) & $3.99 \pm 0.03(\mathrm{pq})$ \\
\hline CAM110 & $14.3 \pm 0.07$ (hi) & $4.24 \pm 0.02(\mathrm{~d})$ & $4.00 \pm 0.04(\mathrm{pq})$ \\
\hline CAM111 & $11.9 \pm 0.11(\mathrm{u})$ & $2.64 \pm 0.02(\mathrm{~s})$ & $3.55 \pm 0.03(\mathrm{rs})$ \\
\hline CAM116 & $13.1 \pm 0.07$ (qr) & $3.76 \pm 0.03(\mathrm{~g})$ & $3.34 \pm 0.01(\mathrm{~s})$ \\
\hline CAM123 & $13.8 \pm 0.02(\mathrm{jkl})$ & $4.48 \pm 0.03(\mathrm{c})$ & $3.53 \pm 0.10$ (rs) \\
\hline CAM132* & $12.6 \pm 0.01$ (st) & $3.47 \pm 0.01$ (ijk) & $6.86 \pm 0.07$ (b) \\
\hline CAM136 & $12.7 \pm 0.06(\mathrm{~s})$ & $3.14 \pm 0.03$ (op) & $5.73 \pm 0.01$ (ghi) \\
\hline CAM137 & $13.6 \pm 0.01(\mathrm{klm})$ & $2.97 \pm 0.03$ (qr) & $5.52 \pm 0.03$ (ij) \\
\hline CAM170 & $15.8 \pm 0.04(\mathrm{f})$ & $2.44 \pm 0.03(\mathrm{t})$ & $7.49 \pm 0.03(\mathrm{a})$ \\
\hline CAM171 & $14.8 \pm 0.04(\mathrm{~g})$ & $2.95 \pm 0.03(\mathrm{r})$ & $7.04 \pm 0.03(\mathrm{~b})$ \\
\hline CAM173 & $14.1 \pm 0.04$ (ij) & $2.39 \pm 0.01(\mathrm{t})$ & $6.01 \pm 0.06(\mathrm{efgh})$ \\
\hline CAM174 & $14.7 \pm 0.01(\mathrm{~g})$ & $4.16 \pm 0.02(d)$ & $5.70 \pm 0.02$ (hi) \\
\hline CAM175 & $11.2 \pm 0.02(\mathrm{vw})$ & $4.45 \pm 0.03$ (c) & $6.12 \pm 0.01$ (de) \\
\hline CAM187 & $9.6 \pm 0.06(\mathrm{y})$ & $3.38 \pm 0.01(\mathrm{kl})$ & $3.52 \pm 0.01$ (rs) \\
\hline CAM265 & $13.7 \pm 0.06(\mathrm{klm})$ & $2.39 \pm 0.01(\mathrm{t})$ & $6.07 \pm 0.04$ (def) \\
\hline CAM266 & $17.9 \pm 0.05$ (a) & $3.33 \pm 0.02(\mathrm{~lm})$ & $4.39 \pm 0.01(0)$ \\
\hline CAM268 & $11.9 \pm 0.08(\mathrm{u})$ & $3.78 \pm 0.01(\mathrm{~g})$ & $6.37 \pm 0.02(\mathrm{~cd})$ \\
\hline CAM269 & $12.4 \pm 0.05(\mathrm{t})$ & $3.28 \pm 0.04(\mathrm{mn})$ & $6.10 \pm 0.03$ (def) \\
\hline CAM270 & $14.4 \pm 0.03(\mathrm{~h})$ & $3.55 \pm 0.02$ (hi) & $4.10 \pm 0.04(p)$ \\
\hline CAMELIA & $13.4 \pm 0.06(\mathrm{mn})$ & $3.50 \pm 0.01$ (hij) & $3.83 \pm 0.06$ (pqr) \\
\hline KARTNER & $13.9 \pm 0.05(\mathrm{jk})$ & $3.52 \pm 0.02$ (hij) & $5.29 \pm 0.05(\mathrm{jk})$ \\
\hline LIGENA & $10.4 \pm 0.01(\mathrm{x})$ & $3.57 \pm 0.03$ (hi) & $4.50 \pm 0.04(0)$ \\
\hline LINDO & $11.1 \pm 0.06$ (vw) & $3.60 \pm 0.02(\mathrm{~h})$ & $4.37 \pm 0.03(0)$ \\
\hline MORGENSONNE & $13.1 \pm 0.05$ (qr) & $3.50 \pm 0.02$ (hij) & $5.30 \pm 0.03(\mathrm{jk})$ \\
\hline PI650142 & $16.6 \pm 0.06(\mathrm{~d})$ & $3.05 \pm 0.02(p q)$ & $4.83 \pm 0.10(\mathrm{mn})$ \\
\hline PI650146 & $18.1 \pm 0.03(\mathrm{a})$ & $3.20 \pm 0.04$ (no) & $4.78 \pm 0.02(\mathrm{n})$ \\
\hline PI650168* & $13.3 \pm 0.04(\mathrm{pq})$ & $2.64 \pm 0.02(\mathrm{~s})$ & $5.79 \pm 0.06$ (fghi) \\
\hline SOLEDO & $12.1 \pm 0.08(\mathrm{u})$ & $4.78 \pm 0.01(\mathrm{a})$ & $4.92 \pm 0.06(\mathrm{lmn})$ \\
\hline ST. PERNITZEN & $17.2 \pm 0.11(\mathrm{c})$ & $4.24 \pm 0.01(\mathrm{~d})$ & $6.42 \pm 0.04(\mathrm{c})$ \\
\hline UKRAJINSKAJA & $12.8 \pm 0.03$ (rs) & $3.59 \pm 0.01(\mathrm{~h})$ & $4.44 \pm 0.04(0)$ \\
\hline WILEDO* & $11.1 \pm 0.05(\mathrm{w})$ & $4.23 \pm 0.01(\mathrm{~d})$ & $5.10 \pm 0.04(\mathrm{klm})$ \\
\hline WROCLAWSKA & $13.5 \pm 0.03(\mathrm{lmn})$ & $3.42 \pm 0.01(\mathrm{jkl})$ & $5.14 \pm 0.06(\mathrm{kl})$ \\
\hline ZARJA SOCIALISMA* & $13.1 \pm 0.02$ (qr) & $4.85 \pm 0.03(\mathrm{a})$ & $3.63 \pm 0.06$ (rs) \\
\hline Mean & $13.6 \pm 0.32$ & $3.60 \pm 0.10$ & $5.20 \pm 0.16$ \\
\hline P accession & $1399.45^{\wedge}$ & $869.23^{\wedge}$ & $339.94^{\wedge}$ \\
\hline P group ${ }^{\S}$ & $9.49^{\wedge}$ & 0.58 & 2.69 \\
\hline
\end{tabular}

*Camelina winter forms; ${ }^{\circ}$ Data are expressed as $\mathrm{mg} \mathrm{CAE} \mathrm{g}{ }^{-1} \mathrm{DW} \pm \mathrm{SEM} ;{ }^{\sharp} \mathrm{mg} \mathrm{g}{ }^{-1} \mathrm{DW} \pm \mathrm{SEM} ;{ }^{\S}$ groups are camelina winter and spring forms; $\wedge^{\wedge}$ Significant at $\leq 0.01$; the lowercase letters in parentheses within the same row differ significantly by Tukey's range test $(\mathrm{P} \leq 0.05)$. 
Table 3. Pearson correlation coefficients (r) for antioxidant activity and compounds in 47 accessions of Camelina sativa.

\begin{tabular}{lccc} 
& TEAC & TPC & Flavonoids \\
TPC & $0.292^{*}$ & 1 & \\
Flavonoids & -0.118 & -0.002 & 1 \\
\hline Proanthocyanidins & -0.024 & 0.161 & $-0.294^{*}$ \\
\hline
\end{tabular}

${ }^{*}$ Correlation is significant at the 0.01 level.

\section{Correlation between antioxidant activity and antioxidant compounds}

In Table 3 are shown the Pearson correlation coefficients $(\mathrm{r})$ among TEAC, TPC, flavonoids and proanthocyanidins. TEAC was significantly correlated (at 0.01 level) with TPC but not with flavonoids and proanthocyanidins, thus suggesting that phenolics are the main class of substances determining antioxidant activity. Flavonoid and proanthocyanidin contents were instead inversely correlated and this could indicate that the biosynthetic pathways of these compounds compete with each other.

\section{Conclusions}

The current study showed that the flours of camelina have a high antioxidant activity, which derives mainly from the high content of TPC, while the contribution of flavonoids and proanthocyanidins is probably modest. Therefore, interesting accessions for future breeding programs are those with higher TPC content (many of which are spring biotypes). Camelina enriches the animal diets as well as protein, omega-3 and tocopherols (the latter two contained in the residual oil of the meal) also of antioxidants. Moreover, the high content of phenolics as well as contributing to animal health may be important to avoid fat rancidity in camelina meals.

\section{References}

1. McVay KA, Lamb PF. Camelina production in Montana; 2008. Available from: http://msuextension.org/publications/AgandNaturalResources/MT2007

\section{AG.pdf}

2. Pecchia P, Russo R, Brambilla I, et al. Biochemical Seed Traits of Camelina sativa - An Emerging Oilseed Crop for Biofuel: Environmental and Genetic Influences. J Crop Improv 2014;28: 465-83.

3. Quezada N, Cherian G. Lipid characterization and antioxidant status of the seed and meal of Camelina sativa and flax. Eur J Lipid Sci Technol 2012;114:974-82.

4. Zubr J. Oil-seed crop: Camelina sativa. Ind Crops Prod 1997;6:113-9.

5. Colombini S, Broderick GA, Galasso I, et al. Evaluation of Camelina sativa (L.) Crantz meal as an alternative protein source in ruminant rations. J Sci Food Agric 2014;94:736-43.

6. Schill SR. Camelina Meal Approved for Feedlot Cattle. Biodiesel Magazine; 2010. Available from: http://www.biodieselmagazine.com/arti cles/3837/camelina-meal-approved-forfeedlot-cattle

7. Smart Earth Seeds. Camelina approved for broiler chicken meal in Canada; 2015. Available from: https://www. prnewswire.com/news-releases/camelina-approved-for-broiler-chicken-mealin-canada-300021410.html

8. European Commission. Directive 2008/76/CE. 2008. Available from: http://www.eur-lex.europa.eu/ LexUriServ/LexUriServ.do?uri=OJ:L:2 008:198:0037:01:IT:HTML

9. Russo R, Reggiani R. Glucosinolates and Sinapine in camelina meal. Food Nutr Sci 2017;8:1063-73.

10. Matthäus B. Antioxidant activity of extracts obtained from residues of different oilseeds. J Agric Food Chem 2002;50:3444-52.
11. Aziza AE, Quezada N, Cherian G. Antioxidative effect of dietary Camelina meal in fresh, stored or cooked broiler chicken meat. Poult Sci 2010;89:2711-8.

12. Brand-Williams W, Cuvelier ME, Berset C. Use of a free radical method to evaluate antioxidant activity. Lebensm Wiss Technol 1995;28:25-30.

13. Mensor LL, Menezes FS, Leitao GG, et al. Screening of Brazilian plant extracts for antioxidant activity by the use of DPPH free radical method. Phytother Res 2001;15:127-30.

14. Velioglu YS, Mazza G, Gao L, et al. Antioxidant activity and total phenolics in selected fruits, vegetables, and grain products. J Agric Food Chem 2006; 46:4113-7.

15. Butler EJ, Pearson AW, Fenwick GR. Problems which limit the use of rapeseed meal as a protein source in poultry diets. J Sci Food Agric 1982;33:866-75.

16. Rahman MJ, Costa de Camargo A, Shahidi F. Phenolic profiles and antioxidant activity of defatted camelina and sophia seeds. Food Chem 2018;240: 917-25.

17. Pérez-Jiménez J, Neveu V, Vos F, et al. Identification of the 100 richest dietary sources of polyphenols: an application of the phenol-explorer database. Eur J Clinic Nutr 2010;64:112-20.

18. Russo R, Reggiani R. Phenolics and antioxidant activity in flax varieties with different productive attitude. Int Food Res J 2015;22:1736-9.

19. Galasso I, Russo R, Mapelli S, et al. Variability in Seed Traits in a Collection of Cannabis sativa L. Genotypes. Front Plant Sci 2016;7:688.

20. Salminen H, Estévez M, Kivikari R, et al. Inhibition of protein and lipid oxidation by rapeseed, camelina and soy meal in cooked pork meat patties. Eur Food Res Technol 2006;223:461-8.

21. Matthäus B. Antinutritive compounds in different oilseeds. Fett/Lipid 1997; 99:170-4.

22. Russo R, Reggiani R. Antinutritive compounds in twelve camelina sativa genotypes. Am J Plant Sci 2012;3:140812. 